\title{
The Pope and the ontogeny of persons
}

John Godfrey

\section{In his recent book Crossing the Threshold of Hope, Pope John Paul II airs his views on human reproduction. The pity is that he ignores most of modern genetics and embryology.}

"THE concept of 'person' is not only a marvellous theory; it is at the centre of the human ethos. . . in this field more than in any other, collaboration among pastors, biologists and physicians is indispensable". Thus the Pope, in his new book Crossing the Threshold of Hope. In a discussion of St Thomas Aquinas, he writes: "It is not good that his thought has been set aside in the post-conciliar period; he continues, in fact, to be the master of philosophical and theological universalism". Why, then, does the Pope dispense with both modern biological knowledge and Aquinas's teachings when dealing with the issues of human reproduction?

The fundamental biological and ethical issue he raises is the origin of an individual person during life before birth. There is no moment when human life starts. It is clear that both the egg and the sperm are alive, and that their life is human, and that life is continuous from one generation to the next. Yet life, at this stage, is not yet that of a person.

The Pope accepts the misconception that there is an instant when fertilization happens. The process of fertilization is complex, taking about two days. It can involve more than one sperm nucleus, at least for a time. During this period genetic identity is yet to be established. There is a rapid and irreversible change at the activation of the egg. Activation, though rapid, is not instantaneous. Its very speed is probably an evolutionary adaptation of eggs to inhibit fertilization by many sperms. The activation that blocks polyspermy has two distinct phases: the first is quick but incomplete, the second slower but complete. A more severe difficulty is that activation, essential though it is to further development, precedes the chromosomal events that establish the genetic identity of the zygote. So a new individual cannot have her or his origin at activation. For about the first four days, all the genetically determined properties of the fertilized egg are maternal. Only after this do paternal genes begin to act, with gene expression characterizing the new individual.

Even then, stable individuality is some way off. Genetically different cells may still be exchanged between twins. Until a couple of weeks after fertilization a single embryo may still divide to produce identical twins. The component parts of what now becomes an unambiguous individual gradually develop. Crucial to the function of the brain is the laying down of insula- tion along the nerve cells. This starts late in pregnancy but is not complete until after birth.

The picture of the nascent human that emerges from modern embryology is one of seamless change. There is no biological discontinuity that would be a candidate for a moment of unique philosophical significance, whether the advent of the individual person or the infusion of the soul. Thus, we should envisage human persons coming into being by continuous progression during ontogeny, as they did during phylogeny; as each bright day is imperceptibly created during dawn. So the rights of, and our duty towards, the unborn must similarly grow gradually.

It is understandable that ethical thinking should have been founded on obsolete biology. Roman Catholic doctrine is that the soul is infused during pregnancy at a particular, but unspecified, time. The present teaching of the Pope, and his church, short of doctrine, is that there is a serious possibility that this time is that of conception. Assuming that this is so avoids the danger of committing unintended homicide. I am not sure if 'conception' is meant to mean implantation, or the fertilization that precedes it. The distinction is not trivial. Many fertilized eggs fail to implant quite naturally. Is each of these to be considered the death of a person, even though most pass away unnoticed? Other eggs may not lead to a pregnancy because the woman is using an intrauterine device as a contraceptive. However, this acts to prevent implantation in the uterus, not fertilization. Aquinas, for long the received philosopher of the Catholic church, based his views on the observations and opinions of Aristotle. He believed that animation (ensoulment) occurred in three stages that were completed around 40 days after conception in the case of males, or 90 days in the case of females. Apart from the exotic error about the supposed difference between the sexes, based on the misleading evidence available to him, Aquinas's thoughts have, as so often, a disturbingly modern ring. His view that ensoulment is progressive is more nearly in tune with our present knowledge of biology than the instantaneous picture of events that the Pope adopts. Until the late nineteenth century, Christian tradition, following Aquinas, tended to grade the protection to the incipient person according to the stages of its development.

The Vatican has serious problems on the issues associated with human reproduction, with both the laity and the priesthood. The bare facts of demography show that many Catholics do not practise what is preached by their church. The gulf between Rome and Italy on contraception and abortion is clear from social surveys and from the permissive legislation that was brought in by the Italian parliament. This might not be so serious if leading thinkers within the church were not so divided. The protest links liberal thinking on reproduction with objection to what is seen as authoritarian reaction to it by the Vatican.

Not only has the Catholic church recently taught that all stages of human development are morally equivalent but it has also adopted an unbending moral legalism in the application of the consequences of this view. This rigidity is not in keeping with important strands of traditional teaching. Aquinas held that fairness or good sense (Epikeia) should be used to recognize when human law might be inappropriate in a particular case. In his words: "Laws are made for human actions. But such actions are individual and concrete situations, and they are infinitely variable" and "The law should not be followed when to do so would be wrong". His theory of exceptions is in contrast to current unbending interpretation of his theory of natural law. The application of Epikeia enhances justice, revealing glimpses of a higher 'law beyond the law'. It has been possible to ignore his humane view because he wrote so briefly of it in his Summa Theologiae, probably because of the way he fitted it into the symmetrical formal design of his work.

In a finite world with limited resources, the biological issues with which the Pope deals affect everyone. The recent United Nations population conference made little progress partly owing to pressure from the Vatican (see Nature 371, 185; 1994). Pope John Paul should, first, consider afresh Aquinas's writing on fairness, and on the unique nature of people and their circumstances; and, second, look at the light that modern genetics and embryology sheds on the concept of a person and of her or his origin. He could then properly advise people on how best to lead their sexual and reproductive lives.

John Godfrey, associate of the Centre for Human Ecology, University of Edinburgh, is at 41 Lawford Road, London NW5 2LG, UK. 